\title{
Data report: geochemical characterization of a lithified horizon of Challenger Mound, Hole U1317B'
}

\author{
Chizuru Takashima, ${ }^{2}$ Masako Hori, ${ }^{3}$ and Akihiro Kano ${ }^{2}$
}

\section{Chapter contents}

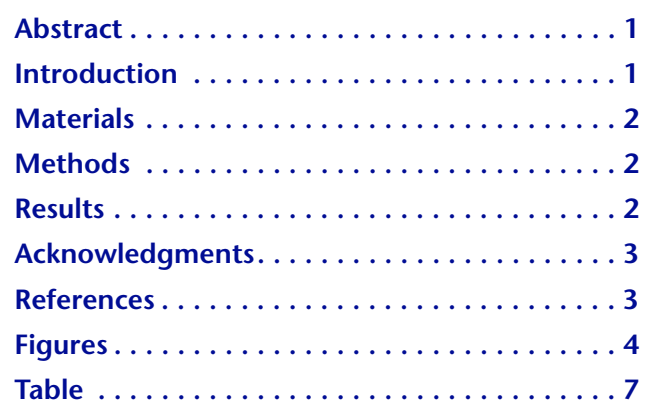

\section{Abstract}

The sediments of Challenger Mound, drilled during Integrated Ocean Drilling Program Expedition 307, show alternations of darker and lighter colored layers in $\sim 10 \mathrm{~m}$ intervals. Lithified horizons often observed in the lighter layers were interpreted as deposits of interglacial periods. We performed high-resolution analysis of minor elements ( $\mathrm{Mg}$ and $\mathrm{Sr}$ ) and stable isotopes for $33 \mathrm{~cm}$ long sections that contain lithified horizons. The $\mathrm{Sr} / \mathrm{Ca}$ ratio, carbonate content, and oxygen and carbon stable isotopes show significant correlation to one another. We also observed mottled parts composed of framboidal pyrites at the levels where carbonate contents and $\mathrm{Sr} / \mathrm{Ca}$ ratios are high. The results suggest an association among coral skeletons, bacterial sulfate reduction, and carbonate precipitation. It is suggested that sulfate-reducing bacteria were responsible for decomposing organic matter in coral skeletons and induced the precipitation of carbonate.

\section{Introduction}

Integrated Ocean Drilling Program (IODP) Expedition 307 was the first attempt to drill through a deepwater coral mound, Challenger Mound, in Porcupine Seabight. Sediments from on-mound Site U1317 contain abundant deep-sea corals, mostly Lopheria pertusa, and show a cyclic change of repeated darker colored and lighter colored layers at $\sim 10 \mathrm{~m}$ intervals. The darker layers are less calcareous and contain better preserved corals, whereas the lighter layers are more calcareous and contain partly dissolved corals (Titschack et al., 2006). Because the mound sediments developed in the late Pliocene and early Pleistocene (e.g., Kano et al., 2007), glacial and interglacial environmental change was considered to be reflected by these cyclic lithological changes (Williams et al., 2006).

The mound sediments, especially the lighter layers, are partly lithified. Chemical analysis of the pore water predicted microbially mediated organic matter decay and carbonate mineral precipitation (Ferdelman et al., 2006). This process is responsible for transforming the unlithified mound sediments into a conical limestone body over the next several million years.

This study focuses on geochemical properties of a lithified lighter layer and provides information to understand the lithification processes. 


\section{Materials}

The analytical material was collected from interval $307-\mathrm{U} 1317 \mathrm{~B}-13 \mathrm{H}-4,0-33 \mathrm{~cm}$, which is equivalent to 114.50-114.83 mbsf (meters below seafloor). This 33 $\mathrm{cm}$ long core section contains four levels of well-lithified material at 5.0-5.5, 13.0-14.0, 16.0-17.0, and $21.5-22.5 \mathrm{~cm}$ from the top. These lithified materials have a mottled appearance. The section is mostly continuous, except for an interval from 29.0 to 29.5 $\mathrm{cm}$.

\section{Methods}

The core section was divided in $5 \mathrm{~mm}$ intervals after avoiding identifiable coral pieces. Each subspecimen was powdered and used for geochemical analyses, such as cation $\left(\mathrm{Ca}^{2+}, \mathrm{Mg}^{2+}\right.$, and $\left.\mathrm{Sr}^{2+}\right)$ concentrations, carbonate content, and carbon and oxygen isotopic compositions.

The cation concentrations were measured by atomic absorption (Shimadzu AA-646). A $~ 50 \mathrm{mg}$ powdered sample was put into a $1.5 \mathrm{~mL}$ plastic tube and dissolved first with $0.6 \mathrm{~mL}$ of $10 \%$ acetic acid and then with $0.6 \mathrm{~mL}$ of $20 \%$ acetic acid. The reacted solution was centrifuged for $10 \mathrm{~min}$ to separate insoluble residue. The sample solution was diluted with $18.2 \mathrm{M} \Omega$ Milli-Q ultra-high purity water to the appropriate ionic strength, to which $1 \mathrm{M} \mathrm{HNO}_{3}$ containing $1 \%$ $\mathrm{La}$ and $0.5 \% \mathrm{Cs}$ in $10 \%$ volume of the sample solution was added. These treatments minimize the interference effect caused by silicic acid and phosphoric acid, which can form refractory ionic compounds with $\mathrm{Ca}^{2+}$ and $\mathrm{Mg}^{2+}$ and result in a measuring error of $<10 \%$. Carbonate contents were calculated from cation concentrations and sample weight.

Carbon and oxygen isotope ratios were measured by gas mass spectrometry using a Finnigan delta mass spectrometer attached to a gas separation system (Thermo as Bench). In this system of isotopic analysis, the samples were reacted with purified $\mathrm{H}_{3} \mathrm{PO}_{4}$ under $1 \mathrm{~atm}$ He in a sealed glass bottle. Reaction temperature and time are $55^{\circ} \mathrm{C}$ and $3 \mathrm{~h}$, respectively. The reactant $\mathrm{CO}_{2}$ was, together with $\mathrm{He}$, first introduced to the gas chromatograph, and other components, such as $\mathrm{H}_{2} \mathrm{O}$, were separated. The separated $\mathrm{CO}_{2}$ was then introduced to the mass spectrometer, which measured isotopic composition. The measured carbon and oxygen isotopic ratios were normalized with a laboratory standard (Solnhofen limestone; $\delta^{13} \mathrm{C}=-0.47 \%$ o, $\delta^{18} \mathrm{O}=-5.04 \%$ ) calibrated against NBS19 $\left(\delta^{13} \mathrm{C}=+1.95 \%\right.$, $\delta^{18} \mathrm{O}=-2.20 \%$ versus Vienna Peedee belemnite). Repeated measurements of the laboratory standard $(n=22)$ showed that the re- producibility of $\delta^{13} \mathrm{C}$ and $\delta^{18} \mathrm{O}$ was within $\pm 0.20 \%$ o and $\pm 0.27 \%$, respectively.

The intensively mottled part of the sample was dried at room temperature and hardened with ethanol-diluted epoxy resin (Maruto Eposet). A recommended ratio of ethanol and resin is $2: 1$ or $1.5: 1$, and the resin permeates into hollow spaces of the sample. Thin sections made from the hardened samples were observed with an optical microscope for lithified textures.

The insoluble residues left after acid treatment were also observed by scanning electron microscopy (SEM; JEOL JXA-8200).

\section{Results}

The results are compiled in Table $\mathbf{T} 1$ and presented in vertical profiles (Fig. F1). Instead of element concentrations, $\mathrm{Mg} / \mathrm{Ca}$ and $\mathrm{Sr} / \mathrm{Ca}$ are shown in Figure F1. $\mathrm{Mg} / \mathrm{Ca}$ ratios range from 0.3 to $1.5, \mathrm{Sr} / \mathrm{Ca}$ ratios range from 0.6 to 1.9 , and the two ratios are inversely correlated $\left(R^{2}=0.58\right)$ (Fig. F2). Incorporation of $\mathrm{Sr}$ and $\mathrm{Mg}$ to $\mathrm{CaCO}_{3}$ largely depends on carbonate mineralogy (Morse and Mackenzie, 1990). Sr/Ca ratio is high in the aragonite fraction that likely originated from corals in the case of the mound sediments. On the other hand, $\mathrm{Mg} / \mathrm{Ca}$ ratio is high in calcite, such as foraminiferal tests. However, the exception is calcareous nannoplankton, which that has low-Mg calcite skeletons (e.g., Stoll et al., 2002).

Carbonate contents fluctuate from 45 to $73 \mathrm{wt} \%$. At the levels where carbonate content is high, the $\mathrm{Sr} / \mathrm{Ca}$ ratio is also high but the $\mathrm{Mg} / \mathrm{Ca}$ ratio is generally low (Fig. F2).

The $\delta^{13} \mathrm{C}$ values range from $-6.08 \%$ to $-1.91 \%$, and the $\delta^{18} \mathrm{O}$ values range from $0.42 \%$ to $2.88 \%$. Where both values are low, the $\mathrm{Sr} / \mathrm{Ca}$ ratio and carbonate contents are high. These levels correspond to mottled lithified horizons (Fig. F1).

Cross-plots of geochemical properties are shown in Fig. F2. Carbon and oxygen isotopes show a positive correlation $\left(R^{2}=0.45\right)$. $\mathrm{Sr} / \mathrm{Ca}$ and $\mathrm{Mg} / \mathrm{Ca}$ ratios represent a negative correlation. The most distinct correlation was obtained between oxygen isotopes and $\mathrm{Sr} /$ Ca ratios $\left(R^{2}=0.72\right)$ (Fig. F2), and the correlation coefficient between carbon isotopes and $\mathrm{Sr} / \mathrm{Ca}$ ratios is also significant $\left(R^{2}=0.56\right)$. These negative correlations are likely reflected by an abundance in the aragonitic coral fraction. It is widely known that skeletons of $L$. pertusa bring disequilibrium values of both $\delta^{13} \mathrm{C}$ and $\delta^{18} \mathrm{O}$, which are far lower than the equilibrium values (Adkins et al., 2003). 
The thin section images and sketch are shown in Figure F3A-F3D. The sediments are mainly composed of clastic corals, mostly L. pertusa, and matrix. In thin section, it was observed that the mottled parts are mainly positioned around coral skeletons (Fig. F3A-F3D). This is consistent with the result that high $\mathrm{Sr} / \mathrm{Ca}$ ratios correspond to the mottled parts.

We observed that the residues from the mottled parts were black and clearly differ from the white to gray colored residues from the other subsamples. SEM observation identified the black residues as framboidal pyrites. They are spherical aggregates $\sim 10 \mathrm{~mm}$ in diameter, which are composed of subcrystals 1 2 $\mathrm{mm}$ wide (Fig. F3E). The origin of framboidal pyrite has been debated since Love (1957). However, in our case, activities of sulfate-reducing bacteria (SRB) might be the process inducing precipitation of framboidal pyrites. SRB decompose organic matter by the following reaction,

$$
2 \mathrm{CH}_{2} \mathrm{O}+\mathrm{SO}_{4}{ }^{2-} \rightarrow 2 \mathrm{HCO}^{3-}+\mathrm{H}_{2} \mathrm{~S} .
$$

Therefore, the framboidal pyrites were formed around coral containing organic matter. The bacterial sulfate reduction also increases alkalinity and induces carbonate precipitation. A similar process by SRB has been also observed in lithification of modern stromatolites (Reid et al., 2000; Andres et al., 2006).

\section{Acknowledgments}

Thanks are expressed to the Integrated Ocean Drilling Program (IODP) for samples and data and the Center for Deep Earth Exploration (CDEX) for funding efforts. We thank the anonymous reviewer for providing constructive comments to the manuscript. We thank Yoshihiro Shibata for SEM observations and Hayami Ishisako for preparing thin sections. We would like to thank the members of scientific party and the crew of the JOIDES Resolution on IODP Expedition 307. Japan Agency for Marine-Earth Science and Technology supported this study.

\section{References}

Adkins, J.F., Boyle, E.A., Curry, W.B., and Lutringer, A., 2003. Stable isotopes in deep-sea corals and a new mechanism for "vital effects." Geochim. Cosmochim. Acta, 67(6):1129-1143. doi:10.1016/S00167037(02)01203-6

Andres, M.S., Sumner, D.Y., Reid, R.P., and Swart, P.K., 2006. Isotopic fingerprints of microbial respiration in aragonite from Bahamian stromatolites. Geology, 34(11):973-976. doi:10.1130/G22859A.1

Ferdelman, T.G., Kano, A., Williams, T., and the IODP Expedition 307 Scientists, 2006. IODP Expedition 307 drills cold-water coral mound along the Irish continental margin. Sci. Drill., 2:11-16. doi:10.2204/ iodp.sd.2.02.2006

Kano, A., Ferdelman, T.G., Williams, T., Henriet, J.-P., Ishikawa, T., Kawagoe, N., Takashima, C., Kakizaki, Y., Abe, K., Sakai, S., Browning, E.L., Li, X., and the Integrated Ocean Drilling Program Expedition 307 Scientists, 2007. Age constraints on the origin and growth history of a deep-water coral mound in the northeast Atlantic drilled during Integrated Ocean Drilling Program Expedition 307. Geology, 35(11):1051-1054. doi:10.1130/G23917A.1

Love, L.G., 1957. Micro-organisms and the presence of syngenetic pyrite. Q. J. Geol. Soc. London, 113:429-440.

Morse, J.W., and Mackenzie, F.T., 1990. Geochemistry of Sedimentary Carbonates: Amsterdam (Elsevier). doi:10.1016/S0070-4571(08)70329-7

Reid, R.P., Visscher, P.T., Decho, A.W., Stolz, J.F., Bebout, B.M., Dupraz, C., Macintyre, I.G., Paerl, H.W., Pinckney, J.L., Prufert-Bebout, L., Steppe, T.F., and DesMarais, D.J., 2000. The role of microbes in accretion, lamination and early lithification of modern marine stromatolites. Nature (London, U. K.), 406(6799):989-992. doi:10.1038/35023158

Stoll, H.M., Ziveri, P., Geisen, M., Probert, I., and Young, J.R., 2002. Potential and limitations of $\mathrm{Sr} / \mathrm{Ca}$ ratios in coccolith carbonate: new perspectives from cultures and monospecific samples from sediments. Philos. Trans. $R$. Soc., A, 360(1793):719-747.

Titschack, J., Foubert, A., Freiwald, A., Ferdelman, T.G., Kano, A., Williams, T., Henriet, J.-P., and the IODP Expedition 307 Scientists, 2006. X-ray computed tomography and image analyses as tools for coral quantification and identification in cold-water coral mounds (Challenger Mound, Porcupine Seabight, IODP Expedition 307) (17th International Sedimentological Congress, Fukuoka, Japan, 27 August-1 September 2006).

Williams, T., Kano, A., Ferdelman, T., Henriet, J.-P., Abe, K., Andres, M.S., Bjerager, M., Browning, E.L., Cragg, B.A., De Mol, B., Dorschel, B., Foubert, A., Frank, T.D., Fuwa, Y., Gaillot, P., Gharib, J.J., Gregg, J.M., Huvenne, V.A.I., Léonide, P., Li, X., Mangelsdorf, K., Tanaka, A., Monteys, X., Novosel, I., Sakai, S., Samarkin, V.A., Sasaki, K., Spivack, A.J., Takashima, C., and Titschack, J., 2006. Cold-water coral mounds revealed. Eos, Trans. Am. Geophys. Union, 87(47):525. (Abstract) doi:10.1029/ 2006EO470001

Initial receipt: 7 June 2008

Acceptance: 14 April 2009

Publication: 16 June 2009

MS 307-201 
Figure F1. Vertical profiles of chemical properties. Carbon and oxygen isotopic values of the section contained lithified horizons from Hole U1317B. At mottled lithified horizons (gray bands), carbonate content and $\mathrm{Sr} / \mathrm{Ca}$ ratio represent high values.

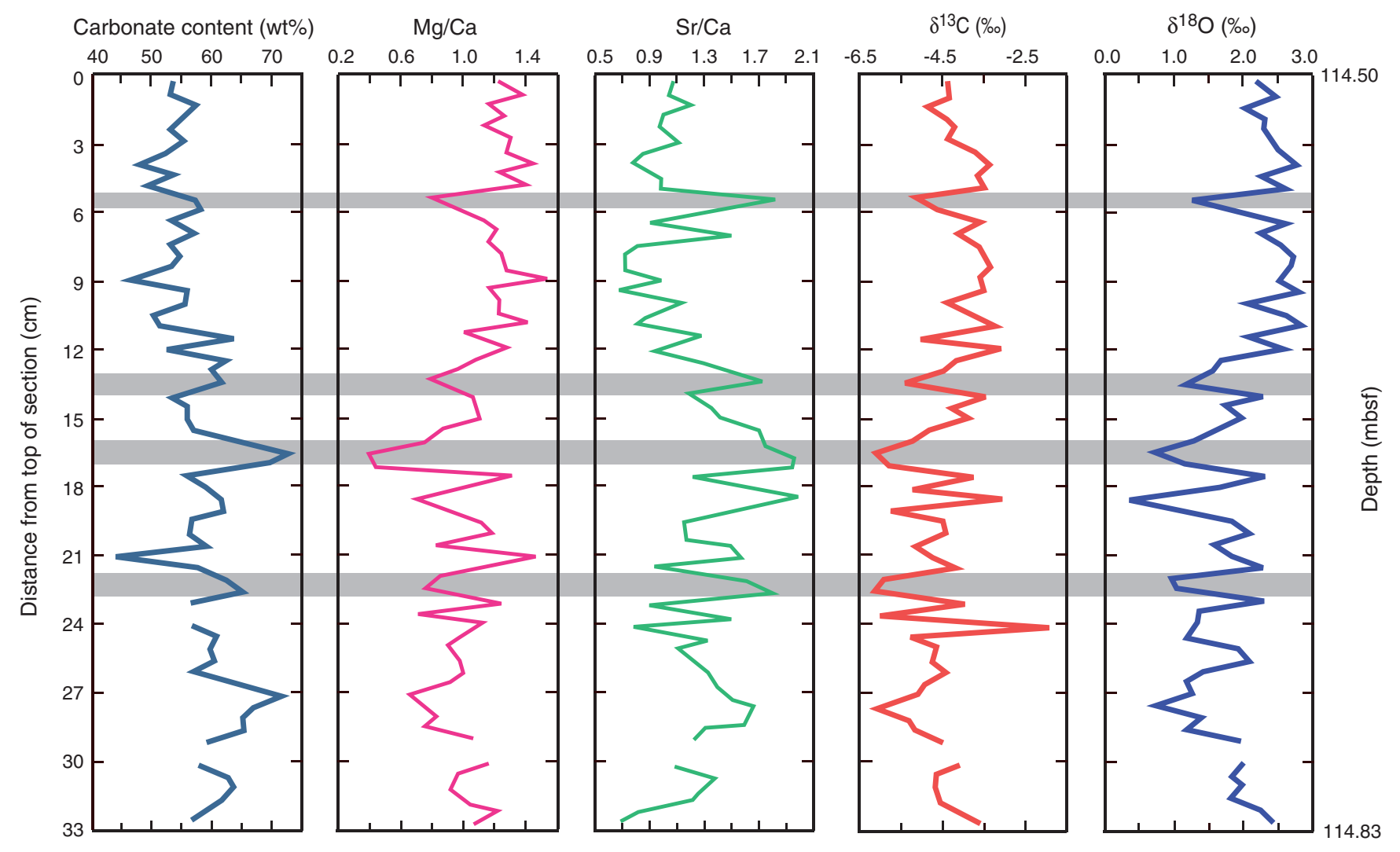


Figure F2. Cross-plots of isotope and chemical components. All cross-plots indicate high correlation coefficients.
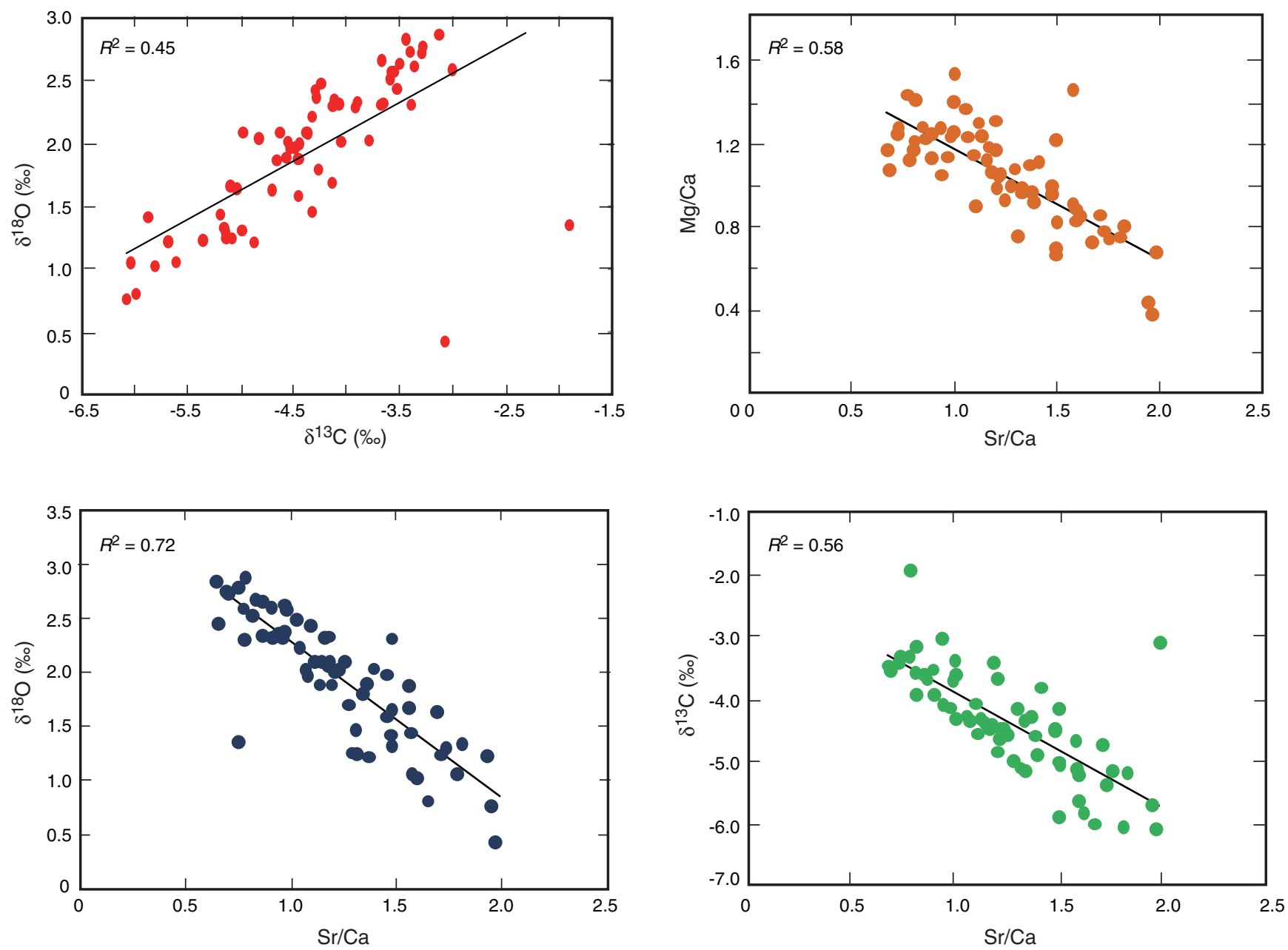
Figure F3. Thin section and SEM images of mottled lithified horizons. A. Sketch of mottled lithified horizon. Pink $=$ coral skeletons, black circles $=$ framboidal pyrites, red $=$ brachiopods, green $=$ echinoids, blue $=$ cement . B. Low-magnification thin section image showing lighter colored coral skeletons with darker colored fringes. C, D. Enlarged images showing darker colored fringes containing framboidal pyrites. E. Framboidal pyrites.

A

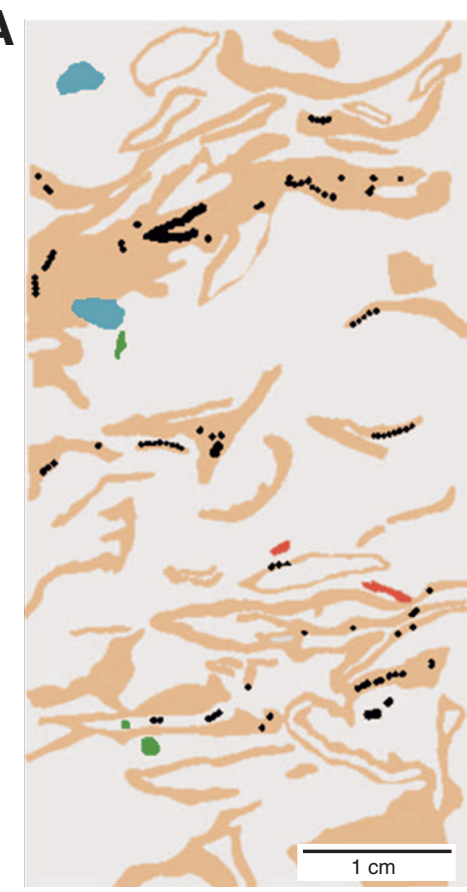

B
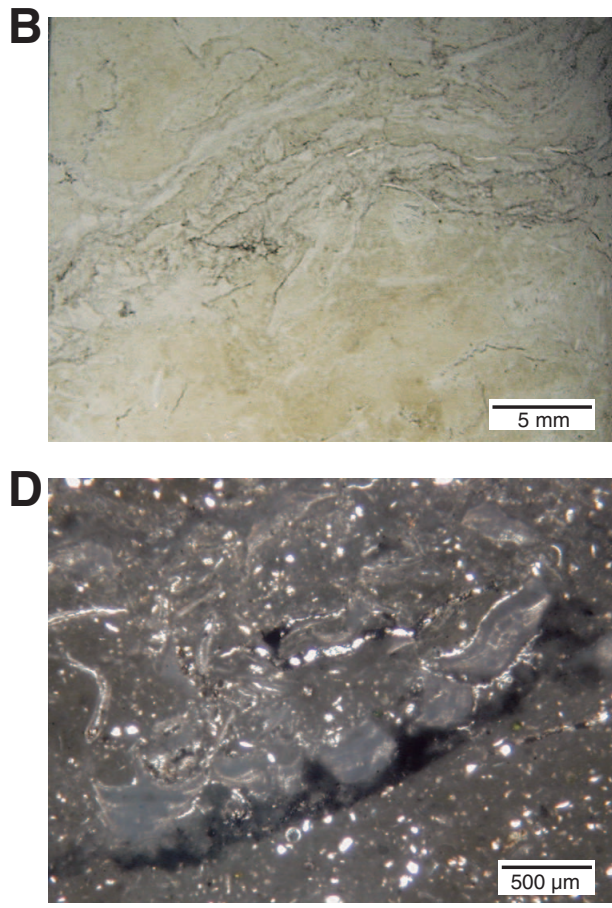

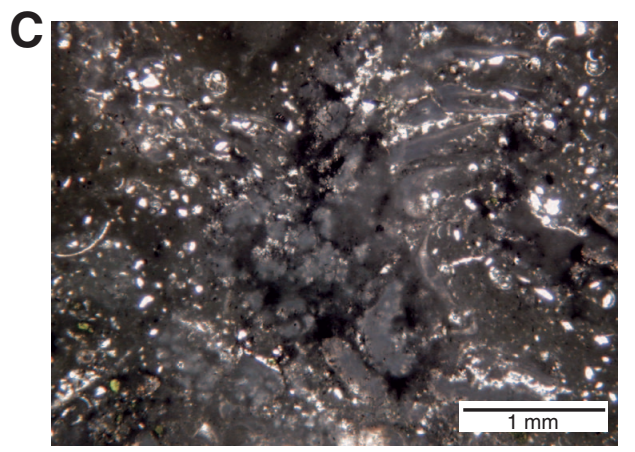

E

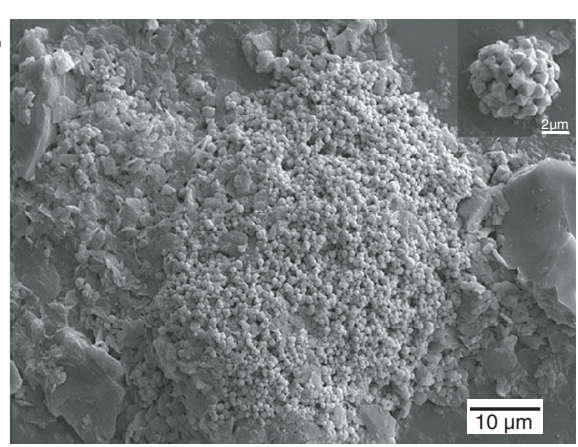


Table T1. Component data. (See table notes.)

\begin{tabular}{|c|c|c|c|c|c|c|}
\hline $\begin{array}{l}\text { Distance from } \\
\text { top of section } \\
(\mathrm{cm})\end{array}$ & $\begin{array}{c}\mathrm{Sr} \\
(\mathrm{ppm})\end{array}$ & $\begin{array}{c}\mathrm{Ca} / 100 \\
(\mathrm{ppm})\end{array}$ & $\underset{(p p m)}{M g}$ & $\begin{array}{c}\text { Carbonate } \\
\text { (\%) }\end{array}$ & $\begin{array}{l}\delta^{13} \mathrm{C} \\
(\% 0)\end{array}$ & $\begin{array}{l}\delta^{18} \mathrm{O} \\
(\% 0)\end{array}$ \\
\hline $0-0.5$ & 64.3 & 60.7 & 74.5 & 53.9 & -4.33 & 2.22 \\
\hline $0.5-1.0$ & 46.5 & 44.4 & 60.5 & 53.7 & -4.25 & 2.49 \\
\hline $1.0-1.5$ & 52.2 & 43.7 & 50.9 & 57.9 & -4.83 & 2.05 \\
\hline $1.5-2.0$ & 61.7 & 62.3 & 77.9 & 55.8 & -4.29 & 2.38 \\
\hline $2.0-2.5$ & 26.0 & 27.0 & 30.5 & 53.8 & -4.12 & 2.36 \\
\hline $2.5-3.0$ & 57.8 & 52.0 & 67.3 & 55.4 & -4.30 & 2.43 \\
\hline $3.0-3.5$ & 47.2 & 56.4 & 71.8 & 52.4 & -3.60 & 2.53 \\
\hline $3.5-4.0$ & 28.9 & 37.7 & 53.9 & 48.8 & -3.29 & 2.78 \\
\hline $4.0-4.5$ & 62.1 & 63.6 & 77.9 & 54.1 & -3.68 & 2.32 \\
\hline $4.5-5.0$ & 47.6 & 48.2 & 67.3 & 49.9 & -3.37 & 2.62 \\
\hline $5.0-5.5$ & 96.2 & 52.8 & 42.2 & 57.9 & -5.16 & 1.33 \\
\hline $5.5-6.0$ & 61.4 & 41.8 & 41.4 & 58.2 & -4.49 & 1.97 \\
\hline $6.0-6.5$ & 27.5 & 31.2 & 35.1 & 53.8 & -3.51 & 2.65 \\
\hline $6.5-7.0$ & 58.2 & 39.0 & 47.2 & 57.8 & -4.14 & 2.31 \\
\hline $7.0-7.5$ & 23.7 & 29.8 & 34.6 & 53.8 & -3.56 & 2.59 \\
\hline $7.5-8.0$ & 51.0 & 71.5 & 88.7 & 55.0 & -3.41 & 2.74 \\
\hline $8.0-8.5$ & 63.6 & 88.2 & 112.0 & 53.7 & -3.30 & 2.73 \\
\hline $8.5-9.0$ & 9.1 & 9.2 & 14.0 & 47.3 & -3.58 & 2.58 \\
\hline $9.0-9.5$ & 22.4 & 33.6 & 39.1 & 56.0 & -3.45 & 2.84 \\
\hline $9.5-10.0$ & 57.2 & 50.6 & 62.3 & 56.1 & -4.37 & 2.09 \\
\hline $10.0-10.5$ & 17.6 & 20.6 & 25.1 & 50.5 & -3.68 & 2.67 \\
\hline $10.5-11.0$ & 37.4 & 46.6 & 65.4 & 51.9 & -3.14 & 2.88 \\
\hline $11.0-11.5$ & 132.2 & 104.1 & 103.4 & 63.7 & -4.98 & 2.09 \\
\hline $11.5-12.0$ & 53.3 & 57.6 & 73.2 & 53.3 & -3.02 & 2.60 \\
\hline $12.0-12.5$ & 81.7 & 63.3 & 67.9 & 62.8 & -4.15 & 1.69 \\
\hline $12.5-13.0$ & 114.6 & 77.9 & 74.5 & 60.1 & -4.46 & 1.58 \\
\hline $13.0-13.5$ & 188.3 & 109.2 & 85.0 & 61.8 & -5.36 & 1.23 \\
\hline $13.5-14.0$ & 108.0 & 91.9 & 97.5 & 54.0 & -3.40 & 2.32 \\
\hline $14.0-14.5$ & 91.9 & 67.6 & 73.8 & 55.9 & -4.28 & 1.80 \\
\hline $14.5-15.0$ & 80.8 & 57.4 & 63.5 & 56.0 & -3.80 & 2.03 \\
\hline $15.0-15.5$ & 117.2 & 68.7 & 58.7 & 57.4 & -4.71 & 1.63 \\
\hline $15.5-16.0$ & 144.6 & 82.7 & 61.1 & 64.0 & -5.15 & 1.29 \\
\hline $16.0-16.5$ & 268.4 & 136.9 & 51.8 & 72.6 & -6.08 & 0.75 \\
\hline $16.5-17.0$ & 189.4 & 97.5 & 42.6 & 69.9 & -5.69 & 1.22 \\
\hline $17.0-17.5$ & 62.3 & 52.2 & 67.9 & 56.1 & -3.66 & 2.33 \\
\hline $17.5-18.0$ & 101.9 & 64.7 & 58.7 & 59.5 & -5.10 & 1.67 \\
\hline 18.0-18.5 & 175.5 & 88.5 & 60.1 & 62.1 & -3.08 & 0.42 \\
\hline $18.5-19.0$ & 106.6 & 67.1 & 59.3 & 61.9 & -5.61 & 1.05 \\
\hline 19.0-19.5 & 68.3 & 59.3 & 66.0 & 57.0 & -4.46 & 1.88 \\
\hline $19.5-20.0$ & 67.7 & 58.2 & 68.6 & 57.0 & -4.39 & 2.10 \\
\hline $20.0-20.5$ & 52.8 & 35.3 & 28.9 & 59.2 & -5.04 & 1.64 \\
\hline $20.5-21.0$ & 120.2 & 76.4 & 111.0 & 44.8 & -4.67 & 1.87 \\
\hline $21.0-21.5$ & 72.2 & 77.6 & 81.1 & 57.8 & -4.08 & 2.32 \\
\hline $21.5-22.0$ & 75.5 & 46.9 & 39.8 & 62.9 & -5.81 & 1.02 \\
\hline $22.0-22.5$ & 119.8 & 66.5 & 49.8 & 65.1 & -6.04 & 1.05 \\
\hline $22.5-23.0$ & 63.3 & 71.5 & 88.7 & 57.1 & -3.91 & 2.34 \\
\hline $23.0-23.5$ & 137.5 & 92.2 & 64.3 & - & -5.88 & 1.42 \\
\hline $23.5-24.0$ & 75.3 & 97.6 & 109.0 & 57.3 & -1.91 & 1.35 \\
\hline $24.0-24.5$ & 107.9 & 81.4 & 77.9 & 60.9 & -5.14 & 1.24 \\
\hline $24.5-25.0$ & 128.0 & 116.6 & 104.5 & 60.2 & -4.54 & 1.97 \\
\hline $25.0-25.5$ & 144.0 & 119.9 & 117.9 & 60.5 & -4.63 & 2.10 \\
\hline $25.5-26.0$ & 144.7 & 109.2 & 107.2 & 57.3 & -4.33 & 1.46 \\
\hline $26.0-26.5$ & 152.7 & 110.3 & 100.7 & 63.3 & -4.88 & 1.21 \\
\hline $26.5-27.0$ & 218.8 & 146.5 & 97.1 & 71.8 & -4.99 & 1.31 \\
\hline $27.0-27.5$ & 157.6 & 94.7 & 68.6 & 67.1 & -5.99 & 0.80 \\
\hline $27.5-28.0$ & 158.3 & 99.8 & 82.5 & 65.1 & -5.19 & 1.44 \\
\hline $28.0-28.5$ & 202.7 & 155.2 & 116.9 & 65.3 & -5.09 & 1.25 \\
\hline $28.5-29.0$ & 80.3 & 65.8 & 69.2 & 59.8 & -4.45 & 2.01 \\
\hline $29.0-29.5$ & - & - & - & - & - & - \\
\hline $29.5-30.0$ & 71.1 & 65.3 & 74.5 & 58.4 & -4.06 & 2.02 \\
\hline $30.0-30.5$ & 82.8 & 60.3 & 58.1 & 63.3 & -4.58 & 1.89 \\
\hline $30.5-31.0$ & 162.6 & 131.1 & 120.9 & 63.7 & -4.56 & 2.02 \\
\hline $31.0-31.5$ & 113.0 & 93.4 & 97.1 & 62.1 & -4.47 & 1.88 \\
\hline $31.5-32.0$ & 79.9 & 100.2 & 120.9 & 59.5 & -3.93 & 2.30 \\
\hline $32.0-32.6$ & 94.0 & 138.9 & 148.7 & 57.2 & -3.54 & 2.45 \\
\hline
\end{tabular}

Notes: Dataset of chemical and isotopic components of the analyzed section. $-=$ no data. 